\title{
Temporary Dysarthria Induced by Irinotecan-Case Report of This Rare Adverse Event
}

\author{
Mayndra Mychelle Landgraf ${ }^{1}$, Cinthia Leite Frizzera Borges Bognar ${ }^{2}$, Raquel Bezerra Guerra ${ }^{2}$, Andrea Morais \\ Borges $^{1}$, Fernando Silva Picon ${ }^{1}$, Gislaine Fernandes Silva ${ }^{1}$, Pamela Carvalho Muniz ${ }^{1}$, Pedro Nazareth Aguiar \\ Junior $^{3}$, Gilberto de Lima Lopes Junior ${ }^{2}$ and Michelle Samora de Almeida ${ }^{1}$ \\ 1. Departamento de Oncologia Clínica e Experimental, Universidade Federal de São Paulo, São Paulo 04039-031, Brazil \\ 2. Centro Paulista de Oncologia and Oncoclínicas do Brasil, Oncoclínicas Group, Sao Paulo 04538-132, Brazil \\ 3. Faculdade de Medicina do ABC, Santo André 09060-870, Brazil
}

\begin{abstract}
This report describes the case of a patient with dysarthria during the administration of the third cycle of Folfiri for the treatment of metastatic colon cancer. After a thorough neurological examination and neuroimaging, structural causes were excluded and thus the dysarthria was attributed to the irinotecan infusion. A slowing down of the infusion rate to 180 min during the 15 subsequent cycles led to the cessation of the episodes of dysarthria. In 2016, it was estimated there will be 134,490 new cases of colorectal cancer with a five-year survival rate of $21 \%$ among patients with metastatic disease. As Irinotecan is often part of the therapeutic regimen in such cases, both in the first and second-line setting, there is a need to report rare adverse outcomes in order to find out ways to better manage of these events. The mechanism by which Irinotecan causes dysarthria is unknown and further research in this area is warranted.
\end{abstract}

Key words: Colon, cancer, Irinotecan, dysarthria, adverse, event, toxicity, CPT-11.

\section{Introduction}

CRC (colorectal cancer) is the third most prevalent cancer among men and the second most prevalent among women in Brazil. The number of new cases estimated in Brazil for the year 2016 was 34,280 and 134,490 in the US [1, 2]. Data from the Surveillance, Epidemiology, and SEER (End Results Program) showed that about $20 \%$ of patients were diagnosed with metastatic disease [2].

The five-year survival rate for localized disease was over $55 \%$ in developed countries and $40 \%$ in developing ones [1]. However, the five-year survival rate for metastatic disease dropt to approximately $21 \%$.

Fluoropyrimidines associated with Oxaliplatin or Irinotecan are the mainstay of treatment against CRCm metastatic CRC). Biological agents may be combined

Corresponding author: Mayndra Mychelle Landgraf, M.D., research fields: colon cancer, medical oncology. in the presence or absence of mutations in the RAS gene [3]. Yet few studies have addressed the appropriate timing or sequencing of these therapies [4], there is data to support that receiving all three cytotoxic drugs leads to improved outcomes [5, 6].

Studies have shown prolonged survival with the use of Irinotecan associated with 5FU (5-Fluororuracil) and Leucovorin compared to the use of 5FU and Leucovorin alone as first-line treatment in CRCm with manageable toxicities. Moreover, chemotherapy schedules that include the use of Irinotecan can facilitate resectability of metastasis and it is also effective in the second-line setting [7]. Its approval by the FDA (food and drug administration) took place in 1996 for use in CRCm after failure of treatment with 5FU. Furthermore in the year 2000 the FDA approved the use of Irinotecan in the first-line setting in combination with 5FU and folic acid [7].

The most common adverse events related to the use of Irinotecan are gastrointestinal, such as acute or 
chronic diarrhea, nausea and vomiting and hematologic toxicity such as anemia, leukopenia and thrombocytopenia. The drug can block the activity of the acetylcholinesterase enzyme through the link of its active metabolite (SN-38), with this enzyme causing a cholinergic syndrome which can include rhinitis, excessive salivation, miosis, lacrimation, diaphoresis, flushing and increased intestinal peristalsis [8]. Rare adverse events include pneumonitis, bradycardia and autoimmune thrombocytopenia [8]. Toxicity to the central nervous system was rarely reported and its mechanism was not well described in the literature [9, 10].

Dysarthria as a side effect of Irinotecan use was a rare event with few cases reported in the literature and even fewer cases described where an effective approach to this symptom was found [9, 11]. Herein, we reported a patient with CRCm who presented with dysarthria, after excluding structural causes. It was determined to be secondary to the Irinotecan infusion. A slowing down of the infusion rate to $90 \mathrm{~min}$ led to the prevention of further episodes of dysarthria.

\section{Case Presentation}

T.S.O is a 30 year old female with no past medical history who presented to the medical service with intestinal obstruction and underwent a rectosigmoidectomy. Pathology showed a tubular adenocarcinoma moderately differentiated with a pathological stage IV, pT4pN2AM1. Staging CT abdomen/pelvis showed a single liver lesion in segment VIII. Her CEA was $3.49 \mathrm{ng} / \mathrm{mL}$. Genetic analysis of the K-RAS showed a K-RAS wild type. She was started on palliative chemotherapy with mFOLFX6, consisting of Oxaliplatin $85 \mathrm{mg} / \mathrm{m}^{2} \mathrm{IV}$, for $2 \mathrm{~h}, \mathrm{D} 1, \mathrm{DL}-$ leucovorin $400 \mathrm{mg} / \mathrm{m} \mathrm{EV}, 2$ hours and 5-FU, $400 \mathrm{mg} / \mathrm{m}$ EV bolus in D1 followed by 5-FU $2,400 \mathrm{mg} / \mathrm{m}^{2} \mathrm{EV}$, on continuous infusion for $46 \mathrm{~h}$, every 2 weeks. She tolerated treatment well and had evidence of stable disease by imaging as per RECIST 1.1 criteria. Four months later follow up abdominal CT scan showed an increased cystic lesion in the left ovarian topography, her known liver lesion was stable and at that time she was found to have a rising CEA to $5.75 \mathrm{ng} / \mathrm{mL}$. She underwent a hysterectomy and oophorectomy, and the pathology confirmed metastatic disease to the ovary. She switched to Folfiri in combination with Cetuximab which consisted Irinotecan $180 \mathrm{mg} / \mathrm{m}^{2} \mathrm{IV}$ for $90 \mathrm{~min}$, followed by DL-leucovorin, $400 \mathrm{mg} / \mathrm{m}^{2} \mathrm{IV}$, for $2 \mathrm{~h}$, with Irinotecan followed by 5 -FU $400 \mathrm{mg} / \mathrm{m}^{2} \mathrm{IV}$ bolus and followed by $5-\mathrm{FU}, 2400 \mathrm{mg} / \mathrm{m}^{2} \mathrm{IV}$ on continuous infusion for $46 \mathrm{~h}$ and Cetuximab $500 \mathrm{mg} / \mathrm{m}^{2}$ IV every 2 weeks. Pre-medication were the following: dexamethasone 20 $\mathrm{mg} \times 1$, aprepitant $150 \mathrm{mg} \times 1$, palonosetron $0.25 \mathrm{mg}$ $\times 1$, diphenhydramine $25 \mathrm{mg} \mathrm{IV} \times 1$; ranitidine $50 \mathrm{mg}$ IV and atropine $0.5 \mathrm{mg} I \mathrm{~V}$.

After her third cycle of Folfiri, she presented with dysarthria, which started soon after Irinotecan infusion and lasted less than thirty minutes. The patient was then admitted to the hospital for further investigation. Imaging done at that time showed a good treatment response. Brain MRI revealed no focal lesions or any evidence of vascular stenosis. In addition, $24 \mathrm{~h}$ video-electroencephalographic monitoring performed during the infusion of chemotherapy and in the presence of dysarthria, showed an organized and symmetrical activity without epileptiform paroxysms.

During the following cycles of Folfiri, the Irinotecan was infused over $180 \mathrm{~min}$, during which the patient did not experience any further episodes of dysarthria. On a future exposition to irinotecan, after a new progression of disease, in agreement with the patient, we opted for the standard 90-min infusion without any recurrent dysarthria.

\section{Discussion}

Irinotecan is a semisynthetic derivative of camptothecin, an isolated alkaloid from Camptotheca acuminate initially synthesized in 1983. It is a pro-drug metabolized in the liver by carboxylesterase enzyme into its active form 
7-ethyl-10-hydroxycamptothecin (SN-38). This molecule binds to topoisomerase I enzyme hindering the relaxation of double-stranded DNA and thus preventing replication in the tumor cells. Irinotecan undergo oxidation by CYP3A4 (cytochrome P450 isoenzyme 3A4), generating inactive metabolite APC (7-ethyl-10-[4-N-(5-aminopentanoic -1-piperidino] carbonyloxycamptothecin) and NPC (7-ethyl -10- [4-(1-piperidino)-1-amino] carbonyloxycamptothecin), besides suffering glucuronidation by UGT1A1 (uridine diphosphate-glucuronosyltransferase enzyme 1A1), leading to the synthesis of SN-38G, which has about $1 / 100$ of antitumor activity, being a virtually inactive metabolite. Subsequently, these metabolites undergo predominantly fecal excretion [12].

Because of the hydrophilic nature of the drug, $80 \%$ of circulating dose is bound to the erythrocyte while the active metabolite $\mathrm{SN}-38$ is almost completely bound to albumin and the lymphocytes. The plasma concentration can be described by a three-phase model, in which the half-live of elimination of Irinotecan and $\mathrm{SN}-38$ are $14.2 \mathrm{~h}$ and $13.8 \mathrm{~h}$, respectively [12]. There is no data on the pharmacokinetics of Irinotecan or SN-38 in CSF (cerebrospinal fluid) of humans. However, a study in primates showed that the level of irinotecan in CSF was $14 \%$ of the plasma level and SN-38 metabolite cannot be detected intrathecally [10]. Animal models studying the pharmakocinetic properties of pegylated Irinotecan have concluded that there is a prolonged exposure in the CNS compared to conventional irinotecan [13].

The active form of SN-38 promotes cytotoxicity and can cause gastrointestinal, hematological and metabolic adverse events by its binding to the enzyme acetylcholinesterase and consequent accumulation of acetylcholine [12]. The neurological toxicity caused by Irinotecan in the form of dysarthria is an uncommon adverse event in which the pathologic mechanism has not been fully elucidated.

Dysarthria is a motor speech disorder characterized by problems with articulation, phonetics and prosody. It can be caused by central or peripheral nervous system damage leading to the loss of control of the oral, pharyngeal and laryngeal muscles. The hypoglossal nerve plays an important role in speech since it innervates the muscles of the tongue and its overstimulation or damage can lead to the development of dysarthria. The density of cholinergic receptors in the brainstem nuclei is relatively high and the application of cholinergic agents results in an increase in the activity of the hypoglossal nerve [11].

Structural and neurological disorders should be ruled out first with the appropriate imaging, given that dysarthria may be a manifestation of injury to the central nervous system by edema, bleeding or metastatic disease which often require immediate intervention. MRI is commonly performed but rarely yields additional information. The measures described in the literature to alleviate this symptomatology are shown in Table 1 [8, 9, 11, 14-20].

Another important consideration is that the chemotherapeutic agents cause the specific toxicity given commonly multiple agents infused during a cycle. Naranjo et al. [6] developed a method for estimating the probability of an adverse event being caused by a certain drug, and in our case report this method was implemented and the highest probability of inducing dysarthria was with Irinotecan [6].

Possible mechanisms by irinotecan causes have been described in the literature. One possible hypothesis is that the elevation of serum levels of Irinotecan or its active metabolite SN-38 lead directly to neurotoxicity [14]. Hamberg et al. [14] described the PK (pharmacokinetics) of the drug in two patients who developed dysarthria and compared it to asymptomatic control, they determined that the pharmacokinetics of both groups was similar [14]. Higher concentrations of irinotecan in the cerebrospinal fluid have also been hypothetically related to the pathophysiology of this adverse event. Arguing against this hypothesis are patients with CNS 
Table 1 Reported cases of irinotecan-induced central nervous system toxicity.

\begin{tabular}{|c|c|c|c|c|c|c|c|c|c|c|c|c|}
\hline & & inotecan & & & & CNS Syn & pptoms & & & & & \\
\hline Ref & $\begin{array}{l}\text { Dosagem } \\
\mathrm{g} / \mathrm{m} 2\end{array}$ & $\begin{array}{l}\text { Infusionminut } \\
\text { es }\end{array}$ & CNS Symptons & Initiation & Duration & Reversible & Recurrence & $\begin{array}{l}\text { Tachyphyla } \\
\text { xis }\end{array}$ & $\begin{array}{l}\text { Acutecholinergi } \\
\text { csyndrome }\end{array}$ & $\begin{array}{l}\text { Atropine } \\
\text { use }\end{array}$ & Premedication & $\begin{array}{l}\text { Concurrentmedi } \\
\text { cation }\end{array}$ \\
\hline $\begin{array}{l}\text { Baz D. V., } \\
\text { et al. }\end{array}$ & 150 & 30 & $\begin{array}{l}\text { Dysarthria, motor } \\
\text { aphasia }\end{array}$ & Few minutes & $45 \mathrm{~min}$ & Yes & Yes & No & No & No & $\begin{array}{l}\text { ondansetron, } \\
\text { dexamethasoneand } \\
\text { atropine }\end{array}$ & 5-FU \\
\hline $\begin{array}{l}\text { Gomez, J., } \\
\text { et al. }\end{array}$ & 80 & 60 & $\begin{array}{l}\text { Tremor, ataxia, } \\
\text { dysarthria }\end{array}$ & Not reported & $16 \mathrm{~h}$ & Yes & Yes & No & No & $\begin{array}{l}\text { Yes, } \\
\text { solvedall }\end{array}$ & $\begin{array}{l}\text { dolasetron, } \\
\text { dexamethasoneandatropi } \\
\text { ne }\end{array}$ & $\begin{array}{l}\text { Gemcitabine } \\
\text { leucovorin, 5-FU }\end{array}$ \\
\hline $\begin{array}{l}\text { Lee, K. A., } \\
\text { et al. }\end{array}$ & 180 & $\begin{array}{l}120 / 180 \\
\text { Cycles } 2 \& 3 \\
/ 240 \text { after }\end{array}$ & Dysarthria & $90 \mathrm{~min}$ & 150 min & Yes & $\begin{array}{l}\text { Partial } \\
\text { (tonguetwis } \\
\text { ting) }\end{array}$ & Yes & No & No & $\begin{array}{l}\text { Metoclopramide ( first } \\
\text { cicle),palonosetron, } \\
\text { atropine }\end{array}$ & Folfiri \\
\hline $\begin{array}{l}\text { Hamberg, } \\
\text { P., et al. }\end{array}$ & $\begin{array}{l}35075 \% \\
\text { dose } \\
\text { Cycle } 2\end{array}$ & $90 \min$ & Dysarthria & $15 \mathrm{~min}$ & $4 \mathrm{~h}$ & Yes & Yes & unknown & No & $\begin{array}{l}\text { Yes, did not } \\
\text { solve } \\
\text { symptoms }\end{array}$ & $\begin{array}{l}\text { Granisetron and } \\
\text { dexamethasone atropine } \\
\text { started on second cicle }\end{array}$ & No \\
\hline $\begin{array}{l}\text { Hamberg, } \\
\text { P., et al. }\end{array}$ & $520 \mathrm{mg}$ & Not reported & Dysarthria & $30 \mathrm{~min}$ & $2.5 \mathrm{~h}$ & Yes & Yes & Yes & Not reported & Yes & $\begin{array}{l}\text { granisetron and } \\
\text { dexamethasone, atropine } \\
\text { on Cycle } 2\end{array}$ & No \\
\hline $\begin{array}{l}\text { Dressel, A. } \\
\text { J., et al. }\end{array}$ & 350 & Not reported & Dysarthria & $45 \mathrm{~min}$ & $24 \mathrm{~h}$ & Yes & Yes & Yes & No & No & $\begin{array}{l}\text { atropine } \\
\text { dexamethasoneondansetr } \\
\text { on }\end{array}$ & No \\
\hline $\begin{array}{l}\text { De Marco, } \\
\text { S., et al. }\end{array}$ & 180 & 60 & Dysarthria, aphasia & $30 \min$ & $15 \mathrm{~min}$ & Yes & $\begin{array}{l}\text { Not } \\
\text { reported }\end{array}$ & $\begin{array}{l}\text { Not } \\
\text { reported }\end{array}$ & No & No & $\begin{array}{l}\text { dexamethasone } \\
\text { ondansetron and atropine. }\end{array}$ & Folfiri \\
\hline $\begin{array}{l}\text { Matsuoka, } \\
\text { A., et al. }\end{array}$ & 180 & 90 & Dysarthria & $90 \mathrm{~min}$ & $2 \mathrm{~h}$ & Yes & No & No & Yes & $\begin{array}{l}\text { Yes, solved } \\
\text { all }\end{array}$ & $\begin{array}{l}\text { palonosetron and } \\
\text { dexamethasone/ atropine } \\
\text { started on Cicle } 2\end{array}$ & Folfirinox \\
\hline $\begin{array}{l}\text { Chandar, } \\
\text { M., et al. }\end{array}$ & 180 & Not reported & $\begin{array}{l}\text { Weakness, paralysis } \\
\text { of extremities, } \\
\text { aphasia }\end{array}$ & Not reported & $2 \mathrm{~h}$ & Yes & No & $\begin{array}{l}\text { Not } \\
\text { reported }\end{array}$ & No & No & $\begin{array}{l}\text { dexamethasoneondansetr } \\
\text { on, atropine }\end{array}$ & Folfirinox \\
\hline $\begin{array}{l}\text { Ramirez, K. } \\
\text { G., et al. }\end{array}$ & 180 & $\begin{array}{l}90 / 120 \\
\text { Cycle2/ } 135 \\
\text { Cycle 3/90 }\end{array}$ & $\begin{array}{l}\text { Dysarthria, tongue } \\
\text { swelling, bilateral } \\
\text { blepharospasm }\end{array}$ & $\begin{array}{l}30 \mathrm{~min} / 90 \\
\text { min Cycle 2/ }\end{array}$ & $24 \mathrm{~h}$ & Yes & Yes & Yes & No & No & $\begin{array}{l}\text { Palonosetron, } \\
\text { dexamethasone, } \\
\text { fosaprepitant, atropine } \\
\text { prior to cycles } 1,3 \text {, and } 4\end{array}$ & Folfiri \\
\hline $\begin{array}{l}\text { Related } \\
\text { Case }\end{array}$ & 180 & $90 / 180 / 90$ & Dysarthria & Few min & $30 \mathrm{~min}$ & Yes & Yes & Yes & No & No & $\begin{array}{l}\text { Dexamethasone } \\
\text { atropine, ranitidine, } \\
\text { Aprepitant } \\
\text { palonosetron } \\
\text { diphenhydramine, }\end{array}$ & Folfiri \\
\hline
\end{tabular}


tumors. One would see higher frequency of dysarthria in these individuals which does not occur [14]. Another possibility outlined in the literature is the overstimulation of the hypoglossal nerve by accumulation of acetylcholine; however, this hypothesis is challenged by the concept of atropine preventing systemic cholinergic events but, in most cases, often does not prevent dysarthria [14, 15]. Only Gomez et al. [9] reported a case of a patient who presented dysarthria associated to ataxia and tremors with complete resolution of the symptoms after administering atropine [9]. In this case dysarthria was not an isolated symptom, and the dose used was relatively lower to those administered in other case reports $\left(80 \mathrm{mg} / \mathrm{m}^{2}-350 \mathrm{mg} / \mathrm{m}^{2}\right)$ [9, 14-15].

Furthermore, in this case the event was fully reversible and does not justify the discontinuation of the drug [15]. The duration of the event may vary between $15 \mathrm{~min}$ [16] and $24 \mathrm{~h}$ [17], but in most reported cases there was spontaneous resolution of the symptom after a few hours [11, 14]. Moreover, several studies reported that the event presented tachyphylaxis, meaning subsequent cycles were less severe [14]. Concerning treatment, there is no standard of care. Few case reports describe successful therapeutic interventions for this symptom. Regarding atropine, only one case report presented resolution of the dysarthria with its use [9]. Lee et al. [11] described the case of a patient who presented with dysarthria after the 3rd cycle of chemotherapy with $180 \mathrm{mg} / \mathrm{m}^{2}$ of irinotecan in a 120 min-infusion associated to 5-FU and folinic acid every 2 weeks (Folfiri regimen) that did not recur after the increase in the irinotecan infusion time to $180 \mathrm{~min}$ on the 3 subsequent cycles and 240 min on the last 6 cycles of treatment [11]. The hypothesis carried out by the authors is that the lowest peak of the drug and its active metabolite SN-38 serum would have reduced the cholinergic toxicity of the drug, but this hypothesis could not be confirmed by the authors given the lack of pharmacokinetic studies. In the case reported previously we opted to increase the infusion time and there was also no recurrent dysarthria [11].

\section{Conclusions}

Dysarthria induced by Irinotecan is a rare event and the mechanism by which it causes this toxicity is not fully understood. This adverse event is self-limited and it has no known long-term sequela, allowing continuation of therapy. Further studies possibly using functional MRI or PET scan with N-[11C] -methyl-4-piperidyl acetate [21] during chemotherapy infusion may provide further insight into the mechanism of drug toxicity and might help guide therapeutic interventions.

\section{References}

[1] Instituto Nacional do Câncer. 2016. "Estimates for the Year 2016 of Incidence Rates per 100 Thousand Inhabitants and Number of New Cases of Cancer, by Sex and Primary Location.” Accessed July 22, 2016. http://www.inca.gov.br/estimativa/2016/tabelaestados.asp ?UF=BR.

[2] SEER Stat Fact Sheets. 2016. "Colon and Rectum Cancer: Surveillance, Epidemiology, and End Results Program.” Accessed July 22, 2016. http://seer.cancer.gov/statfacts/html/colorect.html.

[3] Van Cutsem, E., Köhne, C. H., Láng, I., Folprecht, G., Nowacki, M. P., Cascinu, S., et al. 2011. "Cetuximab Plus Irinotecan, Fluorouracil, and Leucovorin as First-Line Treatment for Metastatic Colorectal Cancer: Updated Analysis of Overall Survival according to Tumor KRAS and BRAF Mutation Status.” J Clin Oncol. 29 (15): 2011-9.

[4] Goldberg, R. M., Rothenberg, M. L., Van Cutsem, E., Benson, A. B., Blanke, C. D., Diasio, R. B., et al. 2007. "The Continuum of Care: A Paradigm for the Management of Metastatic Colorectal Cancer.” Oncologist 12 (1): 38.

[5] Grothey, A., Sargent, D., Goldberg, R. M., and Schmoll, H. J. 2004. "Survival of Patients with Advanced Colorectal Cancer Improves with the Availability of Fluorouracil-Leucovorin, Irinotecan, and Oxaliplatin in the Course of Treatment.” J Clin Oncol 22 (7): 1209-14.

[6] Naranjo, C. A., Busto, U., Sellers, E. M., Sandor, P., Ruiz, I., Roberts, E. A., et al. 1981. "A Method for Estimating the Probability of Adverse Drug Reactions.” Clin Pharmacol Ther. 30 (2): 239-45. 
[7] Fuchs, C., Mitchell, E. P., and Hoff, P. M. 2006. "Irinotecan in the Treatment of Colorectal Cancer." Cancer Treat Rev. 32 (7): 491-503.

[8] Baz, D. V., Bofill, J. S., and Nogueira, J. A. M. 2001. “Irinotecan-Induced Dysarthria.” JNCI J Natl Cancer Inst. 93 (18):1419-20.

[9] Gomez, J., Sanchez, I., and Ramirez, J. A. 2008. "Irinotecan-induced Dysarthria: An Insight into Its Pathogenesis?” Gastrointest Cancer Res. 2 (4): 209-10.

[10] Blaney, S. M., Takimoto, C., Murry, D. J., Kuttesch, N., McCully, C., Cole, D. E., et al. 1998. "Plasma and Cerebrospinal Fluid Pharmacokinetics of 9-AC (9-aminocamptothecin), Irinotecan (CPT-11), and SN-38 in Nonhuman Primates." Cancer Chemotherapy and Pharmacology 41 (6): 464-8.

[11] Lee, K. A., Hee, W. K., Ji, H. A., Hyoun, J. S., and Hyunah, K. 2013. "Dysarthria Induced by Irinotecan in a Patient with Colorectal Cancer.” Am J Heal Pharm. 70 (13): 1140-3.

[12] Mathijssen, R. H., van Alphen, R. J., Verweij, J., Loos, W. J., Nooter, K., Stoter, G., et al. 2001. “Clinical Pharmacokinetics and Metabolism of Irinotecan (CPT-11).” Clin Cancer Res. 7: 2182-94.

[13] Adkins, C. E., Nounou, M. I., Hye, T., Mohammad, A. S., Hall, T. T., Mohan, N. K., et al. 2015. "NKTR-102 Efficacy versus Irinotecan in a Mouse Model of Brain Metastases of Breast Cancer.” BMC Cancer 15 (1): 685.

[14] Hamberg, P., De Jong, F. A., Brandsma, D., Verweij, J., and Sleijfer, S. 2008. "Irinotecan-induced Central Nervous System Toxicity: Report on Two Cases and
Review of the Literature.” Acta Oncol. 47 (5): 974-8.

[15] Dressel, A. J., van der Mijn, J. C., Aalders, I. J., Rinkel, R. N. P. M., and van der Vlieta, H. J. 2012. "Irinotecan-Induced Dysarthria." Case Rep Oncol 5: 47-51.

[16] De Marco, S., Squilloni, E., Vigna, L., Bertagnolio, M. F., and Sternberg, C. N. 2004. "Irinotecan Chemotherapy Associated with Transient Dysarthria and Aphasia.” Ann Oncol. 15 (7): 1147-8.

[17] Sogabe, S., Yuki, S., Takano, H., Kobayashi, Y., Nakatsumi, H., Sasaki, T., et al. 2011. "A Case of Sigmoid Colon Cancer with Temporary Dysarthria Associated with Irinotecan.” Gan to Kagaku Ryoho 38 (8): 1375-7.

[18] Matsuoka, A., Maeda, O., Inoue, M. I., Ohno, E., Hirooka, Y., Yokoyama, Y., et al. 2015. "Folfirinox-induced Reversible Dysarthria: A Case Report and Review of Previous Cases.” Oncol Lett 10 (4): 2662-4.

[19] Chandar, M., and Marshb, R. W. 2015 "Severe Generalized Weakness, Paralysis, and Aphasia Following Administration of Irinotecan and Oxaliplatin during Folfirinox Chemotherapy." Case Rep Oncol 8 (1): 138-41.

[20] Ramirez, K. G., Koch, M. D., and Edenfield, W. J. 2016. "Irinotecan-induced Dysarthria: A Case Report and Review of the Literature.” J Oncol Pharm Pract. 23 (3): 226-30.

[21] Shimada, H., et al. 2009. "Mapping of Brain Acetylcholinesterase Alterations in Lewy Body Disease by PET.” Neurology 73 (4): 273-8. 